\title{
УДК: 351.85(477)
}

Браніцька Тетяна Ромуальдівна доктор педагогічних наук, професор, завідувач кафедри психолого-педагогічної освіти та соціальних наук Комунального закладу вищої освіти «Вінницька академія безперервної освіти», вул. Грушевського, 13, м. Вінниця, 21100, тел.: (067) 706-63-22, e-mail: tatjanarom4@gmail.com, https://orcid.org/0000-0003-4503-3140

Кащенко Нінель Володимирівна аспірантка кафедри управління та адміністрування Комунального вищого навчального закладу «Вінницька академія неперервної освіти», , вул. Грушевського, 13, м. Вінниця, 21100, тел.: (067) 455-11-02, e-mail: ninelvolodumurivna@gmail.com, https://orcid.org/00000001-9178-205X

Кухар Іван Григорович магістр кафедри управління та адміністрування Комунального вищого навчального закладу «Вінницька академія неперервної освіти», вул. Грушевського, 13, м. Вінниця, 21100, тел.: (098) 669-61-06, e-mail: ivankyxar777@gmail.com, https://orcid.org/0000-0003-3581-3549

\section{КУЛЬТУРНА ДИПЛОМАТІЯ ЯК ІНСТРУМЕНТ ПУБЛІЧНОГО УПРАВЛІННЯ СУЧАСНОЇ СВРОПЕЙСЬКОЇ ДЕРЖАВИ}

Анотація. Стаття присвячена культурній дипломатії, за допомогою якої наша держава зможе не тільки підвищити ефективність зовнішньої політики, а й підняти престиж власної країни; подолати упередженість щодо України; зміцнити міжнародний імідж держави. Культурна дипломатія є одним з найбільш ефективних і значущих засобів реалізації зовнішньополітичної стратегії будьякої держави, що претендує на важливу роль в системі сучасних міжнародних відносин. Однак варто відзначити, що лише другій половині XX початку XXI ст. відбувається активне формування базових принципів публічного управління культурними процесами суспільства в більшості європейських країн. Також протягом останнього десятиліття, як ми можемо спостерігати на прикладі Європейського союзу, формується тенденція до посилення ролі культури в зовнішніх відносинах держав, а також міжнародних та регіональних організацій, використання іiі як свого роду каталізатора розвитку і зміцнення діалогу 3 країнами.У статті досліджено комплекс взаємозв'язків культурної дипломатії як інструменту публічного управління сучасної європейської держави та обгрунтовується думка про те, що Україна поки ще не залучила всі інструменти культурної дипломатії, так званої «м'якої сили» держави. Аналізуються причини, що заважають зміцненню міжнародного іміджу України, визначається роль внутрішньої й зовнішньої політики в створенні іміджу України. Робиться висновок про те, що в Україні повинна проводитися цілеспрямована державна 
політика підтримки позитивних i нейтралізації негативних стереотипів, формування іміджу України в міжнародному просторі, ефективного брендингу й репутаційного менеджменту.

У добу посилення та прискорення глобалізаційних процесів необхідність налагодження міжкультурного діалогу актуалізується, принципово видозмінюючи як основоположні принципи, так власне і цілі його встановлення. Після завершення епохи біполярності виникають та поширюються нові концепції світоустрою, постає необхідність пошуку нових інструментів конкурентного розвитку для держав та інших підходів до здійснення міжнародних відносин. У цьому контексті істотно зростає роль гнучких факторів, посилюється ефективність «м'яких» інструментів впливу на систему міжнародних відносин шляхом просування позитивного іміджу тієї чи іншої країни, заснованого на привабливості цінностей та культури іï нації. Основними механізмами реалізації культурної дипломатії для більшості європейських країн є: поширення власної мови та сприяння іiі вивченню закордоном; роз'яснення культурного надбання; пропаганда різноманітних за сферами та масштабами досягнень країн; навіювання цінностей політичної культури; демонстрація привабливого способу життя. Зважаючи на задекларовані європейські прагнення України, прикладом формування культурної дипломатії можуть стати саме країни Європейського Союзу. Не зважаючи на прикладне значення, проблема культурної дипломатії як інструменту публічного управління залишається маловивченою. Відтак, окреслені моменти зумовлюють значну актуальність обраної теми.

Ключові слова: культурна дипломатія; публічне управління; імідж держави, «м'яка сила» держави, зовнішня політика, внутрішня політика, європейська держава, культурні обміни.

Branitska Tetiana Romualdivna Doctor of Pedagogical Sciences, Associate Professor, Head of the Department of Psychological-Pedagogical Education and Social Sciences of the Vinnytsia Academy of Continuing Education, Municipal Higher Educational Institution «Vinnytsia Academy of Continuing Education», Hrushevskoho St., 13, Vinnytsia, 21100, tel.: (067) 706-63-22, e-mail:tatjanarom4@gmail.com, https://orcid.org/0000-0003-4503-3140

Kashchenko Ninel Volodymyrivna Graduate student of the Department of Management and Administration of the Municipal Higher Educational Institution «Vinnytsia Academy of Continuing Education», Hrushevskoho St., 13, Vinnytsia, 21100, tel.: (067) 455-11-02, e-mail: ninelvolodumurivna@gmail, https://orcid.org/0000-0001-9178-205X

Kuhar Ivan Hryhorovych Master of the Department of Management and Administration of the Municipal Higher Educational Institution "Vinnytsia Academy of Continuing Education», Hrushevskoho St., 13, Vinnytsia, 21100, tel.: (098) 669-6106, e-mail: ivankyxar777@gmail.com, https://orcid.org/0000-0003-3581-3549 


\title{
CULTURAL DIPLOMACY AS AN TOOL OF PUBLIC GOVERNANCE OF THE MODERN EUROPEAN STATE
}

\begin{abstract}
The article is devoted to cultural diplomacy, with the help of which our state will be able not only to increase the effectiveness of foreign policy, but also to raise the prestige of its own country; to overcome prejudice against Ukraine; to strengthen the international image of the state. Cultural diplomacy is one of the most
\end{abstract} effective and significant means of implementing the foreign policy strategy of any state, claiming an important role in the system of modern international relations. However, it should be noted that only the second half of XX early XXI century. there is an active formation of the basic principles of public management of cultural processes in society in most European countries. Also over the last decade, as we can see from the example of the European Union, there is a tendency to strengthen the role of culture in the external relations of states and international and regional organizations, using it as a catalyst for development and strengthening dialogue with countries. The thesis that Ukraine is not yet used all available resources so-called «soft power» substantiates in the article. The reasons that prevent the strengthening of Ukraine's international image are analyzed, the role of domestic and foreign policy in creating the image of Ukraine is determined. It is concluded that Ukraine should pursue purposeful state policy to support positive and neutralize negative stereotypes, forming the image of Ukraine in the international space, effective branding and reputation management. In the context of this problem, cultural diplomacy as a means of interaction with foreign target audiences provides ample opportunities to combine the efforts of internal and external factors for the democratization of transition countries. In the age of intensification and acceleration of globalization processes, the need to establish intercultural dialogue is becoming more relevant, fundamentally changing both the fundamental principles and the actual goals of its establishment.

After the end of the era of bipolarity, new concepts of world order emerge and spread, and there is a need to find new tools for competitive development for states and other approaches to international relations. In this context, the role of flexible factors is significantly increasing, the effectiveness of "soft" instruments of influence on the system of international relations is enhanced by promoting a positive image of a country based on the attractiveness of values and culture of its nation. The main mechanisms for implementing cultural diplomacy for most European countries are: spreading their own language and promoting its study abroad; clarification of cultural heritage; propaganda of achievements of different spheres and scales of countries; instilling the values of political culture; demonstration of an attractive way of life. Given the declared European aspirations of Ukraine, the countries of the European Union can become an example of the formation of cultural diplomacy. Despite its practical significance, the problem of cultural diplomacy as a tool of public administration remains poorly understood. Therefore, the outlined moments determine the significant relevance of the chosen topic.

Keywords: cultural diplomacy; public administration; image of the state; international image of Ukraine; «soft power» of the state, foreign policy; domestic policy; European state; cultural exchanges. 
Постановка проблеми. Сьогодні вся інфраструктура галузі культури залежна від органів влади й перебуває у перманентному стані очікування щодо подальших структурних зрушень. Проблема культурної дипломатії як інструменту публічного управління сучасної європейської держави $є$ важливою складовою зовнішньої та внутрішньої політики України та досі мало вивченою науковцями.

Аналіз останніх досліджень i публікацій. Даною проблематикою займаються вітчизняні та західні дослідники. Слід зазначити, що якщо західних дослідників можна назвати засновниками теорії культурної дипломатії, то в Україні цей напрям дослідження є відносно новий, а його актуалізація пов'язана із європейською інтеграцією нашої держави. Джерельну базу дослідження культурної дипломатії пропоную поділити на чотири умовні групи. Першу групу джерел складають офіційні внутрішньополітичні документи, в яких прописані основи зовнішньої політики держави, іiі принципи, основні напрями та стратегічні пріоритети. Другу групу джерел становлять виступи офіційних представників Європейського Союзу, офіційні заяви, інтерв'ю, що стосуються культурної дипломатії. Третя група джерел представлена документами міжнародних організацій (установчими документами, деклараціями, меморандумами, заявами, звітами, резолюціями). Четверта група джерел складається 3 матеріалів 3 офіційних засобів масової інформації та електронних ресурсів.

Постановка завдання: теоретично обгрунтувати та перевірити, чому Україна не залучила всі наявні ресурси культурної дипломатії як інструменту публічного управління сучасної європейської держави; з'ясувати причини, що заважають зміцненню міжнародного іміджу, показати роль внутрішньої й зовнішньої політики в створенні культурному іміджу України.

Виклад основного матеріалу. Культурна дипломатія, як складова частина публічної дипломатії є важливою сферою зовнішньополітичної діяльності будьякої держави. Публічну дипломатію можна визначити як комплекс заходів, що здійснюються як центральними, так і закордонними органами зовнішніх відносин держави 3 метою дослідження ставлення та інформування іноземної громадськості, а також встановлення контактів за кордоном, з метою покращення іміджу держави та досягнення національних інтересів [3, с. 187]. Культурна дипломатія $\epsilon$ комплексом цілеспрямованих дій спрямованих на здійснення обміну ідеями, інформацією, цінностями, традиціями, віруваннями та іншими аспектами культури, 3 метою сприяння міжкультурному взаєморозумінню. Поняття «культурна дипломатія» $\epsilon$ вужчим i використовується для опису програм культури як одна зі складових зовнішньої культурної політики держави. Культурна дипломатія України полягає в поширенні знань про країну, іiі культурні цінності та традиції. Вона передбачає сприяння різноманітним чинникам культури, мистецтва, освіти та має на меті створення захисту та кар'єрного зростання України на міжнародному рівні.

До поняття культурної дипломатії звертаються, зокрема, такі концепції: концепція «м'якої сили»; концепція «зовнішньої культурної політики» i 
«культурної дипломатії»; концепції «культурного імперіалізму», зокрема концепція «американізації»; концепція взаємного культурного обміну [3, с. 587].

Серед ключових завдань сучасної культурної дипломатії більшість дослідників виділяють: формування іміджу держави; розвиток зовнішньої політики; реформування внутрішньої культурної політики держави, iї модернізація та актуалізація. У 2019 році відзначалось сторіччя культурної дипломатії України 3 нагоди створення та початку закордонного турне Української Республіканської Капели під керівництвом диригента Олександра Кошиця (1919-1924 роках). Гастролі українського хору, як представницької державної інституції Української Народної Республіки, були ініційовані Головою Директорії, Головним Отаманом військ і флоту УНР Симоном Петлюрою 3 метою протидії російській пропаганді та акціям української культури й незалежності в Свропі [7, с. 104].

Закордонне турне Капели відбувалось за сприяння Міністерства освіти та мистецтв і Міністерства закордонних справ УНР, ставши першим проєктом культурної дипломатії в історії України. Саме завдяки цим гастролям світ уперше почув «Щедрик» Миколи Дмитровича Леонтовича, а українська культура і державний престиж України здобули позитивний резонанс у сімнадцяти країнах світу (Австрія, Швейцарія, Франція, Бельгія, Чехія, Нідерланди, Велика Британія, Німеччина, Польща, Іспанія, США, Канада, Мексика, Аргентина, Уругвай, Бразилія, Куба) [8, с. 453].

Разом зі здобуттям незалежності Україна виборола шанс здійснювати власну зовнішню політику, в тому числі у галузі культури. 3 появою демократичних перетворень з'явилася альтернатива інтегруватися у міжнародне культурне середовище. Для нашої країни вибір демократичного шляху розвитку стало основним компонентом «м'якої сили». М'яка сила (з англійської soft power м'яка влада) - концепція, відкрита Джозефом Най для створення можливості отримати бажане через співробітництво і привабливість на відміну від «твердої сили», тобто застосування примусових заходів [2, с. 156]. На думку політолога, у XXI столітті в зовнішній політиці буде заправляти балом не «тверда» сила, як це було в попередні два століття, а «м'яка» сила або іншими словами - влада наративів - розповідь, права людини, демократія. От що сьогодні є важливим у досягненні успіху. «М'яка» сила - це здатність одержувати бажаний результат скоріше через привабливість, чим через примус і підкуп, розумна влада здатна з'єднати «тверду» і «м'яку» силу разом. «Розумна сила» - концепція, що обгрунтовує використання поєднання примусу i винагород 3 привабливістю цінностей та переконань задля досягнення цілей [2, с. 209]. Як вважає науковець, «м'яка» сила бере свій початок з культури. Кожна країна, як і кожна людина або група людей, має потенціал «м’якої» влади. На його думку, «м’якою» силою України є в першу чергу ii демократичний розвиток: «Для США Україна $\epsilon$ привабливою, оскільки ми почуваємо, що вона більше демократична, чим будьяка інша держава» [2, с. 234].

Про ставлення європейців до України після «Євро-2012» свідчать результати соціологічного опитування GFK Ukraine, що проведено за замовленням Інституту світової політики. Іноземців з Свросоюзу опитували на 
виході зі стадіонів під час фінальних футбольних матчів - своєрідний «екзитпол». Футбольний «екзит-пол» показав, що подивитися на ігри в Україні 3 Євросоюзу приїхали в основному молоді люди від двадцяти п’яти до тридцяти п'яти років. Такі зустрічалися соціологам майже в половині випадків $(44,28 \%)$. Більша частина європейських уболівальників (45,61\%) мають вищу освіту. Майже всі - 84,64\% - побували в Україні вперше. Приблизно стільки ж не мають в Україні ні друзів, ні знайомих, а тому вони формували своє уявлення про країну безпосередньо на місці, ще до поїздки - через засоби масової інформації, у яких наша країна перед змаганнями була описана далеко не 3 кращого боку $[1$, c.34]. За даними опитування 2011 року, близько 64\% опитаних європейців ніколи не цікавилися Україною. При цьому лише половина респондентів назвала Україну європейською державою, а три чверті опитаних і зовсім вважали, що їхати сюди небезпечно. Більше третини іноземців не змогли сказати, які види туризму вважають перспективними для України. Лідерами серед туристичних напрямків стало відвідування культурно-історичних пам'яток і сільський туризм (56\% i 44\%). Найвідомішими українцями назвали спортсменів - Андрія Шевченко й братів Кличко. Сама ж Україна непохитно асоціювалася у європейців з салом, писанками і шароварами.

Однак після порівняння того, що вони бачили на телевізійних екранах і в реальності, 52,25\% європейців змінили свою думку про Україну у кращий бік. При цьому, 52,39\% виступають за негайне надання Україні безвізового режиму. Але самими несподіваними були результати відповіді на питання про членство України в Свропейському союзі. Кожний шостий (16,89\%) європейський уболівальник на «Свро-2012» думав, що Україна вже є частиною Євросоюзу. Абсолютна більшість вважає, що Україна повинна бути членом ЄС або найближчим часом $(42,56 \%)$, або після проведення ряду реформ $(30,92 \%)[1$, с.34]. Тобто, лише незначна частина опитаних європейців, висловились проти вступу нашої країни в європейський політичний клуб. Причому, за вступ нашої країни в Євросоюз активніше виступали саме ті, кого заведено вважати «європейськими скептиками». Футбольний чемпіонат зіграв позитивну роль не лише у формуванні зовнішнього, але й внутрішнього іміджу держави. Українці по-іншому подивилися на свою країну. Адже, донедавна ті, хто займалися створенням іміджу України, прагнули зіграти на емоціях міжнародної громадськості та звести Україну в ореол «держави-мучениці», яку завжди пригноблювали й ущемляли. Акцент робився на пережиті невдачі й трагедії Голодомор, руйнівну Громадянську війну, невдачі українського антирадянського підпілля, Чорнобиль. Таким чином, почав формуватися якийсь комплекс неповноцінності України. Чемпіонат «Свро-2012» довів зворотну сторону медалі.

За результатами всеукраїнського дослідження суспільної думки соціологічної компанії Research \& Branding Group, що було проведено 326 червня по 12 липня 2012 року, 73\% українців вважають, що країна в цілому змогла гідно провести футбольний чемпіонат «Євро-2012», 65\% опитаних вважають, що проведення принесло країні більше позитива, 20\% респондентів вважають, що позитив від чемпіонату для України полягає, насамперед, у «визнанні Європою, іміджі й престижі», 66\% українців вважають, що організація 
«Свро-2012» показала здатність країни приймати масштабні спортивні заходи [1, с.64].

Визначними подіями в зростанні іміджу держави стали революції 2004 року та революція Гідності 2014 року, адже, український народ 3 високою активною культурною позицією створював політичний імідж країни перед європейським суспільством та усім світом. Саме культурна дипломатія привернула неабияку увагу державних інституцій , вчених, науковців, дослідників та культурних діячів усього світу, коли з'явилася необхідна потреба в отриманні підтримки міжнародної спільноти для протистояння російській агресії.

Культурні форуми в Дипломатичній академії імені Геннадія Удовенка у червні 2015 року, квітні 2016 року та в червні 2017 року були свідченням зацікавленості держави щодо застосування «м’якої сили» для боротьби 3 викликами гібридної війни. Активні учасники форуму не тільки обмінювалися теоретичними знаннями, розробляли основні напрями діяльності, але й займалися вивченням важливих практичних рекомендацій щодо створення іміджу сучасної європейської країни. Суб’єктами культурної дипломатії $\epsilon$ інститути державної влади, неурядові організації, мистецькі об'єднання, митці, активісти, дипломати, науковці, журналісти та політики. Внесок у формування іміджу України за кордоном роблять зокрема і представники української діаспори.

Наказ Міністерства культури України Про затвердження Примірного порядку організації міжнародних і всеукраїнських професійних, студентських та учнівських мистецьких конкурсів (від 04 травня 2018 року №395) підписано двосторонніми та багатосторонніми угодами про культурне співробітництво. Загальнополітичні договори, які Україна уклала 3 деякими державами Польщею (1992), Францією (1992), Туреччиною (1992), Грузією (1993), Тунісом (1993), Казахстаном (1994), Литвою (1994), Італією (1995), Чехією (1995) - також $\epsilon$ свідченням країн до культурних переговорів та можуть існувати базою для ширших угод про взаємодію та співпрацю. Оскільки Україна залучає Польщу та не залучатиме Білорусь, відповідно, буде різним вплив культурної влади на ці країни. Зі всіх країн Туреччина найбільше успішно використовує культурну силу в зовнішній політиці й одержує кращу прихильність своїх сусідів [4, с. 215].

Здається, що Україні корисно було б взяти до уваги китайський досвід культурної політики - Конфуціанство й використати його з урахуванням власної специфіки. Конфуціанство проголошувало пріоритет моралі над правом $\mathrm{i}$ проголошене державною ідеологією впродовж численних віків аж до початку ХХ століття. Воно відображало перед усім погляди верстви державних чиновників, літераторів, істориків. В Китаї його називали «школою службовців». Конфронтація Китаю зі Сполученими Штатами, дешеві низькоякісні товари та авторитарний комуністичний режим - речі, котрі насамперед спадають на думку при згадці Китай. Погодьтесь, досить суперечливі асоціації як для держави, яка прагне стати новим світовим лідером. Розуміючи, що сильної армії та дипломатії примусу на сьогодні вже недостатньо для успішного просування своїх інтересів, У XXI столітті одним із важливих елементів зовнішньої політики, якому китайський уряд приділяє особливу увагу, стала «м’яка сила». 
Україні варто сконцентруватися на власних соціальних i економічних проблемах, пропагуючи свої реальні успіхи в тих сферах, де $\epsilon$ ресурси позитивного сприйняття західною суспільною думкою. В Україні повинна проводитися цілеспрямована державна політика 3 підтримки позитивних i нейтралізації негативних стереотипів, формування іміджу в міжнародному просторі, ефективного виготовлення брендів та створення репутаційного менеджменту. На державному рівні культурна дипломатія України здійснюється Міністерством закордонних справ, Міністерством культури та інформаційної політики, Українським інститутом, Міністерством молоді та спорту, Міністерством освіти і науки, Українським Інститутом Книги, Державним комітетом телебачення і радіомовлення України. Органи влади на обласному i місцевому рівні можуть розвивати міжнародне співробітництво самостійно чи за підтримки з боку центрального уряду, а саме організовувати мистецькі конкурси, фестивалі, вечори, гастролі, конференції.

У 2015 році було засновано Управління публічної дипломатії, у складі якого були створенні три відділи: публічної дипломатії, культурної дипломатії, іміджевих проєктів та медіа зв'язків. Метою було створення об'єднання митців та громадських діячів культури, щоб через мистецтво розповісти усьому світу про Україну. Всі держави сучасного типу свідомо культивують елементи свого зовнішньополітичного іміджу. Міжнародний імідж допомагає закріплювати політичні успіхи на світовій арені, вишиковує певний асоціативний ряд практично будь-якій дії держави, відіграє найважливішу роль у сфері міжнародних відносин: від того, чи є він позитивним або негативним, залежить успішність проведення зовнішньої політики країни, розвиток торговоекономічних відносин 3 іншими країнами. Процес формування іміджу держави залежить від безлічі факторів - успішності проведення зовнішньої політики держави, особливостей проведення ऑiі внутрішньої політики, ефективності економіки, особливостей ментальності суспільства.

Необхідність просування свого позитивного іміджу усвідомлюється багатьма країнами. Так, наприклад, тільки офіційні щорічні витрати США на підтримку й поліпшення свого іміджу у світі перевищують \$1 мільярд доларів. Білий дім не тільки створює потрібний інформаційний імідж своєї країни через мережу спеціально створених для цього медіа структур, але й активно коректує для цього інформаційну політику в багатьох державах. У Держдепартаменті США офіційно діє так званий центр швидкого реагування, у завдання якого входить корекція іміджу Америки у випадку, якщо він невірно, з погляду Білого дому, подається в закордонних 3МІ. Повноваження цього центра вражають. Йому дозволяється прямо втручатися в редакційну політику закордонних ЗМІ й тиснути на окремих журналістів. Найбільшу кількість коштів на реалізацію іміджевої політики виділяє Китай, у 2009 році - \$ 6,6 мільярда. На формування іміджу витрачаються кошти не лише провідними країнами. Болгарія витрачає на свій імідж 23 мільйонів доларів на рік. За даними МЗС України, бюджет формування позитивного іміджу України за кордоном склав у 2005 і 2006 роках по 20 мільйонів гривень, у 2007 році - близько двадцять мільйонів гривень, у 2008 році - 16 мільйонів гривень. У 2010 році на імідж України було витрачено 8 
мільйонів доларів. Багато це або мало, можна судити відносно бюджету на рекламу російської компанії «Газпром» - 140 мільйонів доларів на рік [6, с. 237].

Міністерство культури та інформаційної політики у свої структурі має Директорат стратегічного планування європейської інтеграції, а також Управління міжнародного співробітництва. Важливим напрямком діяльності $\epsilon$ розроблення, укладення та виконання положень договорів у сфері культури. Наша країна уклала близько вісімдесяти двосторонніх договорів про культурне співробітництво. Міністерство також забезпечує представництво в роботі міждержавних, міжурядових, міжвідомчих комісій, комітетів та робочих груп. Звичайно, за кордоном культурну дипломатію країни здійснюють представники міжнародного посольства. Найурочистішою подією слід вважати дипломатичний прийом з нагоди Незалежності України. Міжнародне посольство також виявляє неабияку увагу до національних свят і значущих подій країни.

32006 року при дипломатичних представництвах України за кордоном працюють культурно-інформаційні центри, в яких робота здебільшого обмежується протокольними заходами «3 інформаційно-роз'яснювальної роботи» (з нагоди Дня Соборності та Свободи України, Міжнародного дня рідної мови, Шевченківських днів), відзначення щорічних ювілейних дат, вшанування пам'яті видатних українців. Поширювана про Україну інформація переважно стосується минулого українського народу та його традиційної культури. У більшості випадків активність центрів передбачає заходи, пов'язані з обмінами делегаціями [10, с. 432]. На сьогоднішній день такі центри є майже у тридцяти країнах світу, які співпрацюють з представниками національних діаспор усього світу та організовують художні виставки, сучасні українські естрадні концерти, народні фольклорні виступи, презентують літературні твори українських письменників.

Український інститут книги, що заснований у 2016 році, є державним закладом у галузі видавничої справи. Український інститут книги відноситься до сфери управління Міністерства культури та інформаційної політики. Метою якого є «підтримка книговидавничої справи, стимулювання читання, сприяння перекладацької діяльності, популяризація української літератури у світі», а найголовнішою функцією визначено - створення та реалізація проєктів, грандів та програм популяризації української літератури за кордоном» [5, с. 231]. Одним iз вирішення проблем Інституту $є$ підтримка українських та іноземних видавництв , які випускають книги українською мовою. Проводяться різноманітні консультації та допомога в отриманні необхідних ліцензій, забезпечується інформація про реальні програми фінансування. За пропаганду української літератури за кордоном відповідає Відділ міжнародних відносин виставкової діяльності та читання.

У червні 2017 року Кабінет Міністрів України отримав та підтримав пропозицію Міністерства Закордонних Справ щодо відкриття Українського інституту. Його метою було проголошено розуміння сучасної європейської держави та зростання довіри до України на міжнародному культурному рівні. А 28 лютого 2018 року за наказом міністра закордонних справ Павла Клімкіна було затверджено Статут державної установи «Український інститут», який вирішував 
такі проблеми, як інтеграція культурного потенціалу та підвищення іміджу України у світі, сприяння міжнародним культурним обміном, популяризація української мови та культури за кордоном, поширення інформації про науковий, освітній та туристичний розвиток країни.

У квітні 2018 року директором закладу було призначено Володимира Шейка. Український інститут працює в таких секторах, як кіно, музика, візуальне мистецтво, література, перформанс - вільне мистецтво, академічні проєкти та програми, крос-секторальні програми, розвиток культурної дипломатії та дослідження. За роки свого існування Іститут заснував ряд програм та реалізував чимало проєктів, наприклад у 2019 році це були «Рік культури Австрія-Україна2019», «Між Києвом і Віднем», «Українська ніч», «Sounds Around Me».

Міністерство інформаційної політики України 2017 року ініціювало створення Концепції популяризації України у світі, якою було передбачено створення єдиного бренду для просування України. У травні 2018 року бренд Ukraine NOW, розроблений креативною компанією Banda Agency, був схвалений Урядом та отримав престижну премію Red Dot Design Award [9, с. 634].

Ukraine Now вважають першою успішною маркетинговою кампанією 3 популяризації України, яку високо оцінюють експерти як в Україні, так і за кордоном. Бренд призначений для використання як онлайн та офлайн; як державними та муніципальними установами, бізнесом та окремими громадянами. Це, зокрема, друковані матеріали, соціальні мережі, радіо, телебачення, зовнішня реклама, транспорт, сувенірна продукція. Допускається використання логотипа 3 державною символікою.

Одним з яскравих прикладів культурної дипломатії із залученням державної й недержавної підтримки є арт-проєкт «Мистецтво Майдану», який правдиво відтворює події Революції гідності українськими митцями. Мандрівна виставка проєкту сімнадцяти українських художників з 2014 по 2018 рік демонструвалася в містах України (десять виставок), Сполучених Штатів Америки (п'ять виставок), Великій Британії (дві виставки), Нідерландах (одна виставка). Одночасність експозиції в різних локаціях та мобільність при транспортуванні стали можливими завдяки роздрукуванню медіа-творів та оцифруванню зображень інсталяцій і живопису, здійснені куратором Наталією Мусієнко й артменеджером Мар'яном Лунівим. Організатори збільшили просвітницьку місію проєкту, надрукувавши вісімнадцять афіш, окремо до кожної експозиції, i змістовну книгу, де зібрано свідчення й документи подій Революції.

До заходів культурної дипломатії у Бельгії можна віднести щорічний фестиваль «Українська Весна», бельгійський кінофестиваль «Бріджес СхідЗахід», люксембурзький кінофестиваль «СinEast», участь української команди у щорічному фестивалі «EatBrussels», виставки українських художників Івана Марчука, Миколи Теліженка, Романа Мініна, Микити Кадана, Алевтини Кахідзе, Едуарда Бєльського, Олександра Кудрявченка, Богдана Голояда, Сергія Святченка, Ігоря Мусіна, Оксани Левченя, Світлани Лебіги, Надії Сеничак та інших. У 2017 році українська Асоціація шеф-кухарів презентувала високу національну кухню під час дегустації вин «Шабо» у Королівському літературномистецькому клубі Брюсселя, а у жовтні 2019 року у місті Арлон було відкрито 
пам'ятник Анні Київській, доньці Великого князя Київського Ярослава, в рамках проєкту «Шлях Королеви» [6, с. 304].

У 2016 р. кіно-дистриб'ютор «Артхаус Трафік» провів Дні українського кіно -Ukraine on Film: Way to Freedom у Амстердамі, а у популярному арт-центрі Spui відбулася дискусія 3 письменницею Катериною Петровською, що була номінована на Європейську літературну премію. Цього ж року арт-агенція Ganka Film та громадська організація Stratcom UA провели комунікативну кампанію Like UA. У рамках якої було знято цілу серію цікавих відеороликів, в яких розповіли про цінності, які об'єднують країни, а також охарактеризували креативний та інноваційний потенціал української молоді. У Гаазі відбувся демонстрація фільму «Герої не вмирають» кінорежисера Ахтема Сеітаблаєва. Стрічку переглянули глядачі нідерландської громадськості урядових та неурядових організацій, дипломатичних місій та української діаспори. Після перегляду фільму відбулося обговорення та дискусії.

Успішне створення позитивного іміджу України в умовах російськоукраїнської війни на Сході України є подія, що акумулювала значну масовість повідомлень у мас-медіа - участь i перемога української співачки кримськотатарського походження Джамали у пісенному міжнародному конкурсі «Євробачення-2016». Співачка представила композицію «1944», написану двома мовами - англійською i кримськотатарською, яка передає трагедію кримськотатарського народу та сім’ї співачки. Слід також враховувати, що, згідно 3 правилами «Свробачення», жителі анексованого Криму не мали права голосувати в українському національному відборі, таким чином, переконлива перемога кримськотатарської співачки, якій більшість ії земляків не могли віддати голоси. Тому фактично, Україна голосувала за Крим і замість Криму, виявляючи таким чином свою підтримку і солідарність.

Переможцем «Євробачення-2021» стала Італія, Україна увійшла в ТОП-5. Гурт «Go-A» загалом отримав 364 бали, посівши п’яте місце у загальному рейтингу, проте за кількістю балів від глядачів - Україна на другому місці. Саме такий високий бал дала глядацька публіка, яка $є$ найправдивішою частиною голосування. Важливим елементом «м'якої сили» в умовах протиборства $\epsilon$ непрямі дії на противника. «Євробачення» можна вважати величезним успіхом української культурної дипломатії.

Висновки. Отже, культурна дипломатія дала старт комплексу цілеспрямованих дій спрямованих на здійснення обміну ідеями, інформацією, цінностями, традиціями, віруваннями та іншими аспектами культури, з метою сприяння міжкультурному взаєморозумінню. Проаналізовано позитивні зрушення та зміни в механізмах реалізації культурної дипломатії України: поширення власної мови та сприяння їі вивченню за кордоном; охорона та збереження культурних надбань; пропаганда різноманітних досягнень країн; навіювання цінностей дипломатичної культури; багатогранність внеску інших культур і цивілізацій; культурне розмаїття європейського суспільства. Культурна дипломатія як інструмент публічного управління надає широкі можливості інтеграції на користь сучасної європейської держави - України. 


\section{Лimepamypa:}

1. Акуленко, ,В. І. (2010). Двосторонні договірні відносини України в сфері охорони і повернення культурних цінностей / В. I. Акуленко // Науковий часопис НПУ імені М. П. Драгоманова. Серія 18: Економіка і право (вип. 8). с. 112.

2. Жук О. (2017). Культурна дипломатія: вікно чи шпарина можливостей / О. Жук // Агора. - вип.18. с. 22.

3. Короткий енциклопедичний словник з культури. - К. : Україна, 2003. - ISBN 966-524105-2. Історія мистецтв : навч. посіб. / О. Л. Шевнюк. - Київ : Освіта України, 2015. - С. 451

4. Луцишин Г. , Гончарук А. (2017). Особливості розвитку культурної дипломатії України в сучасних умовах / Г. Луцишин, А. Гончарук // Humanitarian Vision. - Т. 3. - №1. Львів: Видавництво Львівської Політехніки. с. 27-28.

5. В. А. Малахов. Мистецтво // Енциклопедія історії України : у 10 т. / ред. кол.: В. А. Смолій (голова) та ін. ; Інститут історії України НАН України. - К. : Наук. думка, 2009. T. 6 : Ла- Mi. - С. 668. - ISBN 978-966-00-1028-1.

6.Мусієнко, Н. (2016). Мистецтво в контексті культурної дипломатії: Теоретичні засади та сучасні практики / Н. Мусієнко // Сучасне мистецтво (Вип. 12). с. 130.

7.Пересунько, Тіна (2018). Світовий тріумф «Щедрика» - 100 років культурної дипломатії України (збірник архівних документів) (укр.). Київ: Видавничий дім «АртЕк». c. 200. ISBN ISBN 978-617-7674-01-5.

8. Пересунько, Тіна (2019). Культурна дипломатія Симона Петлюри: «Щедрик» проти «русского мира». Місія Капели Олександра Кошиця (1919-1924) (укр). Київ: Видавничий дім «АртЕк». с. 312. ISBN 978-617-7674-92-3.

9. Помаза-Пономаренко А. Л. Стратегія як засіб стабільного розвитку України [Електронний ресурс] / А. Помаза-Пономаренко // International Scientific Journal, 2015.- № 7. Режим доступу: http://www.internauka.com/uploads/public/14483663697323.pdf

10. Тимошенко Р. Оборонне планування: загальна логіка, структура та взаємозв'язок документів / Р. Тимошенко, М. Лобко // НІО. - 2015. - № 2. - с. 152

\section{References:}

1. Akulenko, V. I. (2010). Dvoctoronni dohovirni vidnocyny Ukrayiny v cferi okhorony i povernennya kul'turnykh tsinnoctey [Bilateral contractual relations of Ukraine in the sphere of protection and return of cultural values ]. Naukovyy chacopyc NPU imeni M. P. DrahomanovaScientific journal of NPU named after MP Dragomanov, 8, 112 [in Ukrainian].

2. Zhuk, O. (2017). Kul'turna dyplomatiya: vikno chy shparyna mozhlyvoctey [Cultural diplomacy: a window or a plethora of opportunities]. Ahora-Agora, 8, 22 [in Ukrainian].

3. Shevnyuk, O.L. (2015) Istoriya mystetstv [Art history]. Kyyiv: Osvita Ukrayiny [in Ukrainian].

4. Lutsyshyn, H. \& Honcharuk, A. (2017). Ocoblyvocti rozvytku kul'turnoyi dyplomatiyi Ukrayiny $\mathrm{v}$ cuchacnykh umovakh [Peculiarities of the development of cultural diplomacy of Ukraine in modern conditions]. Humanitarian Vision, 1(3), (pp. 27-28). L'viv: Vydavnytstvo L'vivc'koyi Politekhniky [in Ukrainian].

5. Malakhov, V.A (2009). Mystetstvo [Art]. Entsyklopediya istoriyi Ukrayiny - Encyclopedia of Ukrainian History (Vols. 6), (p. 668). K.: Nauk. dumka [in Ukrainian].

6. Musiyenko, N. (2016). Myctetstvo v kontekcti kul'turnoyi dyplomatiyi: Teoretychni zacady ta cuchacni praktyky [Art in the context of cultural diplomacy: Theoretical principles and current practices]. Cuchacne myctetstvo - 1 Contemporary art, 12, 130 [in Ukrainian].

7. Peresun'ko, T (2018). Svitovyy triumf «Shchedryka»-100 rokiv kul'turnoyi dyplomatiyi Ukrayiny (zbirnyk arkhivnykh dokumentiv) (ukr.) [Shchedryk's world triumph is - 100 years of cultural diplomacy of Ukraine (collection of archival documents) (Ukr.)]. Kyyiv: Vydavnychyy dim «ArtEk» [in Ukrainian].

8. Pomaza-Ponomarenko, A.L. (2015). Stratehiia yak zasib stabilnoho rozvytku Ukrainy [Strategy as a means of stable development of Ukraine]. International Scientific Journal, 7. 
Retrieved from http://www.internauka.com/uploads/public/14483663697323.pdf [in Ukrainian].

9. Pomaza-Ponomarenko A. L. Stratehiya yak zasib stabil'noho rozvytku Ukrayiny [Elektronnyy resurs] / A. Pomaza-Ponomarenko // International Scientific Journal, 2015.- № 7. - Retrieved from http://www.internauka.com/uploads/public/14483663697323.pdf [in Ukrainian].

10. Tymoshenko, R., Lobko, M. (2015). Oboronne planuvannia: zahalna lohika, struktura ta vzaiemozviazok dokumentiv [Defense planning: general logic, structure and relationship of documents]. Nauka i oborona-Science and defense, 2, 152 [in Ukrainian]. 